\title{
LASER SELECTIVITY ON CLEANING MUSEOLOGIC IRON ARTEFACTS(*)
}

\author{
Gilberto Pereira(1), Margarida Pires $\left.{ }^{(2)}\right)^{(*)}$, Benilde Costa $^{(3)}$ e Fernanda Costa(4)
}

Artigo submetido em Julho de 2007 e aceite em Março de 2008

\begin{abstract}
Three distinct techniques were used to clean Fe alloys objects with surface corrosion. These objects are presently kept in Physics Museum of the University of Coimbra. The techniques used were mechanical, chemical (EDTA solution) and LASER (pulsed $\mathrm{CO}_{2}$ and $\mathrm{Nd}$ :YAG - Q-Switch). The chemical characterisation and the evaluation of the cleaning degree were done by transmission ${ }^{57} \mathrm{Fe}$ Mössbauer spectroscopy.

The results suggest that: the mechanical process of cleaning does not allow total removal of corrosion, reaching easily the substrate and so causing mechanical damage; the cleaning method using EDTA in confined environment and high controlled conditions, removes the corrosion products efficiently, without damaging the surface; and the cleaning methods using LASER although not achieving complete removal of corrosion, show clear characteristics of selectivity when acting on the corrosion layer or on the metal surface.
\end{abstract}

Keywords: Museologic Artefacts, Iron Corrosion, Cleaning Laser

\section{SELECTIVIDADE DA LIMPEZA POR LASER APLICADA A OBJECTOS MUSEOLÓGICOS EM FERRO}

\section{RESUMO}

Afim de estudar processos de limpeza de corrosão em superfícies de ligas de ferro, foram utilizadas três técnicas distintas. As técnicas de limpeza utilizadas foram a limpeza mecânica, a limpeza química (com uma solução de EDTA) e a limpeza por laser. Estas técnicas foram aplicadas a objectos museológicos, pertença do Museu de Física da Universidade de Coimbra. O grau de limpeza obtido pelas diferentes técnicas foi caracterizado quimicamente e avaliado por espectroscopia ${ }^{57} \mathrm{Fe}$ Mössbauer por transmissão.

Os resultados obtidos sugerem que: o processo de limpeza mecânica não remove completamente a corrosão, além de que atinge facilmente o substrato de ferro, causando dano mecânico na superfície; a limpeza química com uma solução de EDTA, realizada em condições controladas e em espaço confinado, remove eficientemente os produtos de corrosão, sem danos visíveis na superfície; por último a técnica de limpeza por laser, embora não removendo a corrosão completamente, mostra características claras de selectividade na actuação sobre a camada de corrosão ou sobre a superfície metálica.

Palavras chave: Objectos Museológicos, Corrosão no Ferro, Limpeza Laser

\section{INTRODUCTION}

Arthur Schawlow's invention "Laser Eraser" was the first known proposal for a laser based cleaning system aiming to correct typed text. Although it was never implemented, this was the first reference to the process of laser cleaning in the early stage of the history of laser applications.

The idea of laser cleaning has been recovered by John Asmus in the early seventies, when using a Ruby laser to do Holography of Venetian Statuary. Using this technique he found out that the stone black crust was removed in the irradiated areas [1].

After this finding, Asmus has investigated further the use of lasers for the cleaning and conservation of different materials Art Artefacts [2-6] and indeed the research and conservation commu- nity have adopted the laser cleaning process, as can be shown by several international research projects (LAMA, RESTOR, CLEANART, ENV4-CT98, DOCT, ALICE, SUCLAT), and networks (TMR, FMRX 980188 or COST G7) and dedicated conferences (LACONA) and huge number of case studies reported in the literature.

However, the removal of superficial corrosion from metal artefacts is not an easy task [7-24], due to the specific type of physical and chemical bonds. Very often, as can be seen from literature, the cleaning process is incomplete or the underneath material is permanently affected. Even so, the use of laser radiation for cleaning iron artefacts is more selective, faster and environmental friendly than other cleaning methods, namely mechanical or chemical ones. Moreover, it can be easily applied on very small [8] or very large [16] objects, easily or remotely accessible.

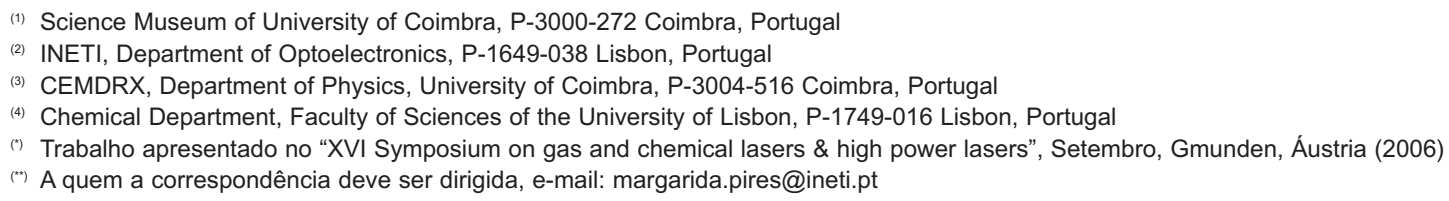


In this work three distinct techniques were used for the cleaning of Fe alloys objects presenting surface corrosion and their efficiency and selectivity compared. The techniques used to remove the corrosion were mechanical, chemical (EDTA solution) and LASER (pulsed $\mathrm{CO}_{2}$ and Nd:YAG - Q-Switch).

\section{EXPERIMENTAL CONDITIONS}

\subsection{Iron artefacts}

Several artefacts and loosen pieces from the Physics Museum of the University of Coimbra were used to perform the cleaning tests:
- Object A, parallelepiped bars from the same instrument, presenting heavy red/brown corrosion in some faces and black light corrosion in others (fig. 1);

- Object B, cylindrical double screws with black surface;

- Object C, an iron key heavily corroded.

Before the application of the cleaning methods, samples of superficial corrosion were removed with a diamond file from the surface of each object, and analysed by ${ }^{57} \mathrm{Fe}$ Mössbauer spectroscopy. The obtained spectra and related quantitative compositional data are presented in figs. 2 and 3.
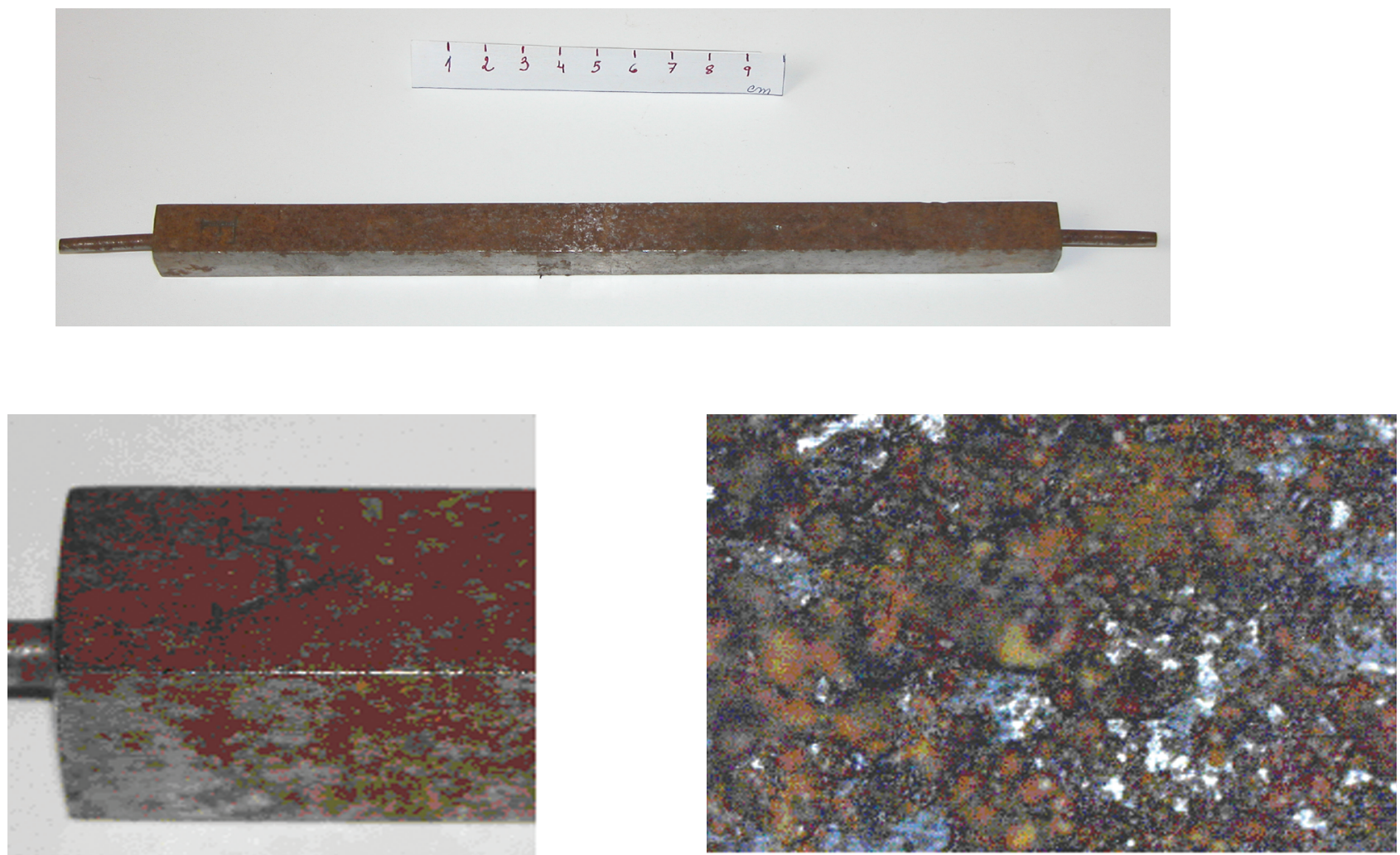

Fig. 1 a - Heavy corrosion areas on iron artefacts (collected sample A1).
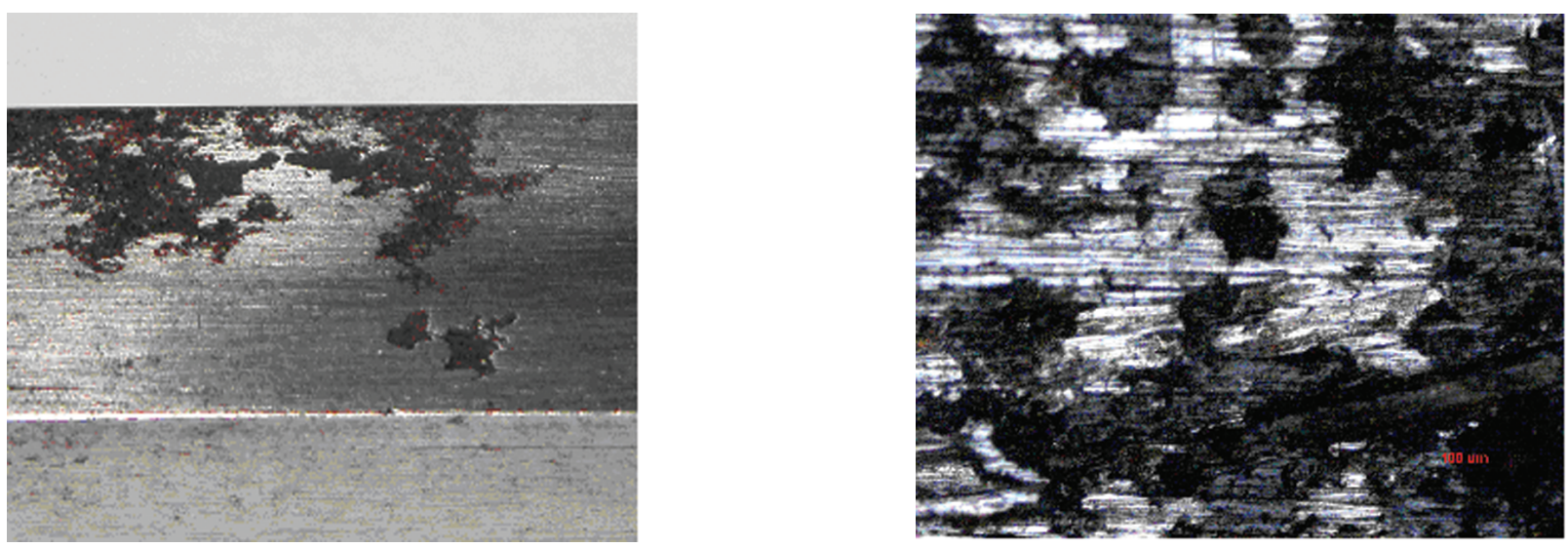

Fig. 1 b - Light corrosion areas on iron artefacts (collected sample A2). 

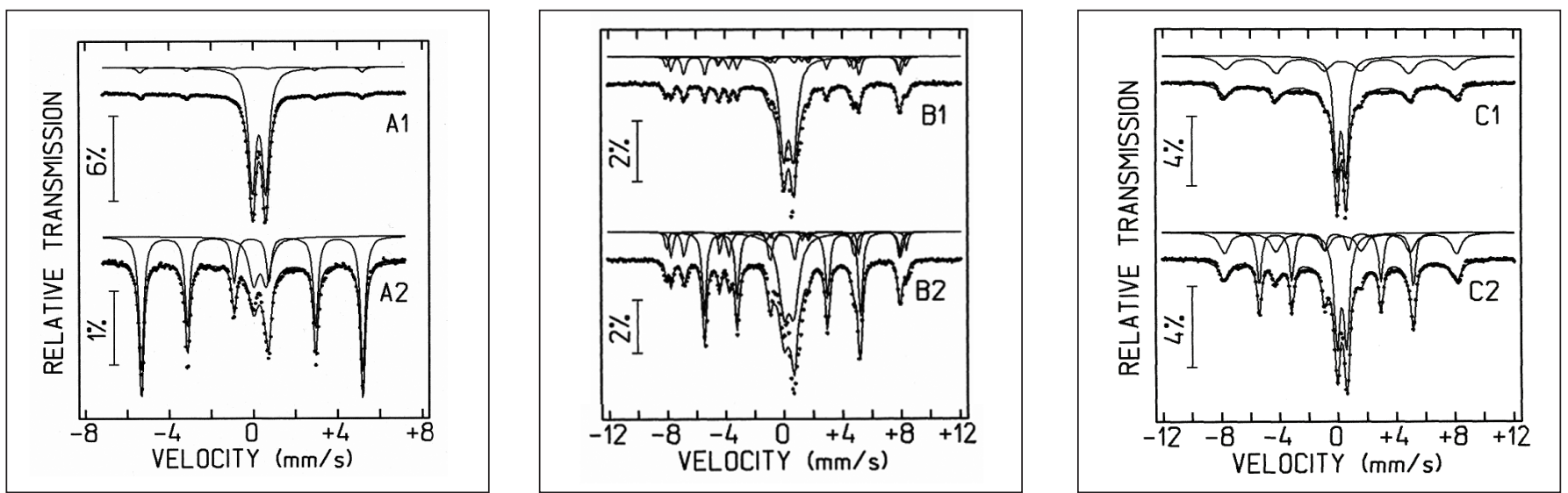

Fig. 2 - Mössbauer spectra of corrosion samples A1 and A2 (from object A), B1 (object B) and C1 (object C).

The analysis shows that the corrosion on the all surface of objects $\mathrm{A}$ is Fe $\mathrm{Fe}^{\mathrm{lll}}$ hydroxide; in sample $\mathrm{B}$, a more complex mixture of iron compounds was found, namely $\mathrm{Fe} \mathrm{ll}$ hydroxide (more abundant), hematite $\left(\alpha-\mathrm{Fe}_{2} \mathrm{O}_{3}\right)$ and magnetite $\left(\mathrm{Fe}_{3} \mathrm{O}_{4}\right)$; sample $\mathrm{C}$ is all composed for Felll hydroxide and hematite.

\begin{tabular}{|c|c|c|}
\hline Sample & Composition & $\%$ \\
\hline \multirow{2}{*}{ A1 } & $\mathrm{Fe}-\alpha$ & 6.7 \\
& $\mathrm{Fe}(\mathrm{OH})_{3}$ & 93.3 \\
\hline \multirow{2}{*}{ A2 } & $\mathrm{Fe}-\alpha$ & 76.0 \\
& $\mathrm{Fe}(\mathrm{OH})_{3}$ & 24.0 \\
\hline \multirow{3}{*}{ B1 } & $\mathrm{Fe}-\alpha$ & 11.8 \\
& $\mathrm{Fe}(\mathrm{OH})_{3}$ & 60.3 \\
& $\alpha-\mathrm{Fe} \mathrm{O}_{3}$ & 6.0 \\
& $\mathrm{Fe}_{3} \mathrm{O}_{4}(\mathrm{~A})$ & 8.9 \\
& $\mathrm{Fe} \mathrm{O}_{4}(\mathrm{~B})$ & 13.0 \\
\hline \multirow{2}{*}{ C1 } & $\alpha-\mathrm{Fe} \mathrm{O}_{3}$ & 48.5 \\
& $\mathrm{Fe}(\mathrm{OH})_{3}$ & 51.5 \\
\hline
\end{tabular}

Fig. 3 - Quantitative data obtained from Mössbauer spectra.

\subsection{Laser irradiation}

For laser cleaning two different pulsed lasers were used, with clearly different pulse characteristics:

a) $\mathrm{CO}_{2}$ laser, model Diamond from Coherent, emitting pulses with wavelength near $10.6 \mathrm{~mm}$, duration of tens of microseconds with a pulse repetition frequency of $1 \mathrm{kHz}$. The expected cleaning mechanism associated with this radiation is mainly thermal (fig. 4 a), due to the long wavelength and relatively long pulse duration.

b) A Nd:YAG laser, Palladio, from Quanta Systems, emitting pulses with wavelength $1.064 \mathrm{~mm}$, duration of 8 nanoseconds in single pulse or with a pulse repetition frequency up to $20 \mathrm{~Hz}$. The expected cleaning mechanism associated with this radiation is mainly photomechanical (fig. 4 b), due to the shorter wavelength and relatively short pulse duration.
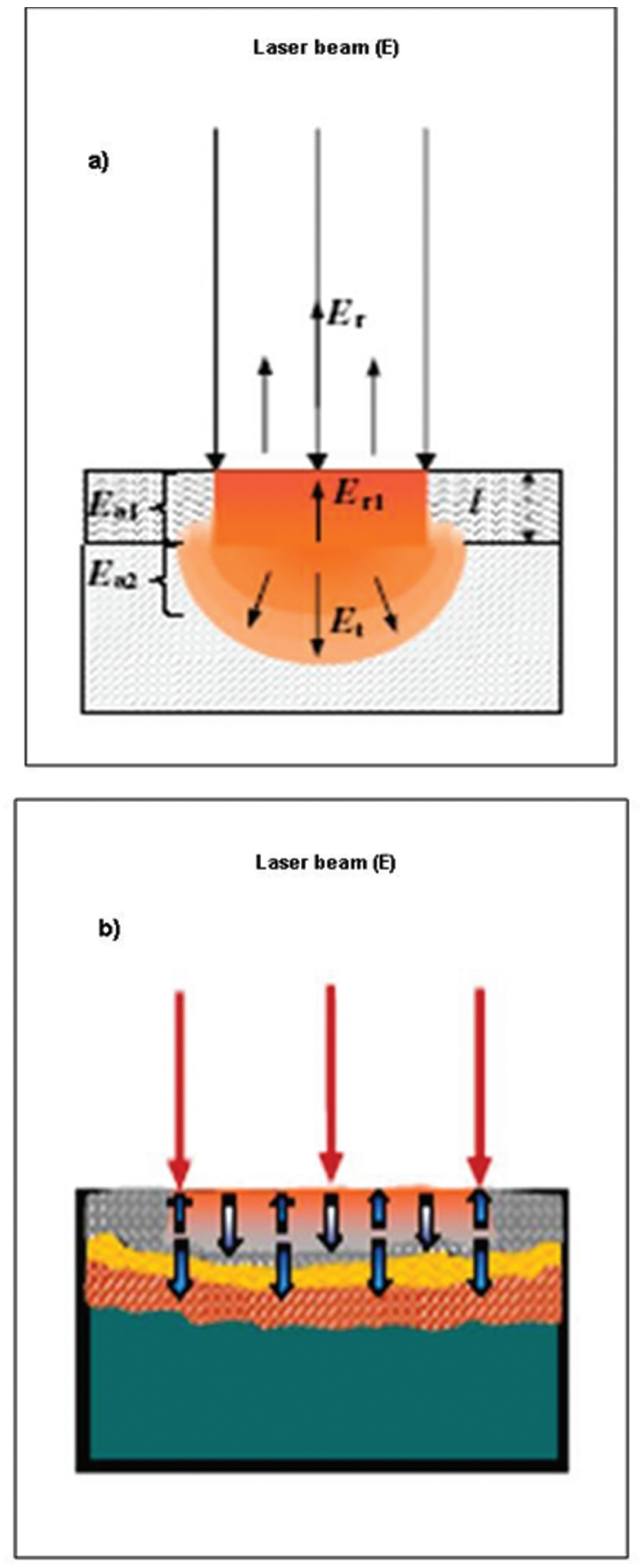

Fig. 4 - Laser cleaning mechanisms.

a) Thermal Cleaning Mechanism;

b) Photomechanical Cleaning Mechanism

(E-energy, a-absorbed, r-reflected, t-transmitted; blue arrows-thermoelastic waves)

(C) S. Siano in "Handbook on the Use of Lasers in Conservation and Conservation Science", 2006. 


\subsection{The analysis techniques}

Aiming to evaluate and compare the cleaning effect of each technique, we have used optical and SEM microscopy, for a qualitative observation, and Mössbauer and EDX spectroscopy for quantitative evaluation.

In order to analyse the chemical composition of the artefact surface, before and after cleaning, Mössbauer spectroscopy of ${ }^{57} \mathrm{Fe}$ isotope has been done using a source of ${ }^{57} \mathrm{Co}$ in a Rh matrix; the emission source was oscillating in the referential of the target (the sample to be analysed) with a speed of $\pm 10 \mathrm{~mm} \mathrm{~s}^{-1}$. The radiation transmitted by the sample was detected and counted by a regular $\gamma$-ray counter.

SEM and EDX were done using a FEG Phillips XL 30 equipment, in order to visualize the surface topography and analyse the elemental composition of the surface.

\section{EXPERIMENTAL CLEANING AND RESULTS}

\subsection{Mechanical cleaning}

De-rusting of iron objects using mechanical processes is the most usual, accessible and inexpensive way. Usually a glass fibre brush, a micro-brace or a piece of steel wool is gently scrubbed on the corroded surface. In this work, a piece of steel wool was used, gently against the corroded object. The process was stopped when there was no more visible corrosion on the surface (fig. 5).

\begin{tabular}{|c|l|l|l|}
\hline C1 & \multicolumn{1}{|c|}{ Original } & $\alpha-\mathrm{Fe}_{2} \mathrm{O}_{3}$ & $48.5 \%$ \\
& & & \\
& & & \\
& & & \\
\hline \multirow{2}{*}{ C2 } & \multirow{2}{*}{ Mech $(\mathrm{OH})_{3}$} & $51.5 \%$ \\
& & $\alpha-\mathrm{Fe}_{2} \mathrm{O}_{3}$ & $33.3 \%$ \\
& & $\mathrm{Fe}(\mathrm{OH})_{3}$ & $36.1 \%$ \\
& & $\mathrm{Fe}-\alpha$ & $30.6 \%$ \\
\hline
\end{tabular}
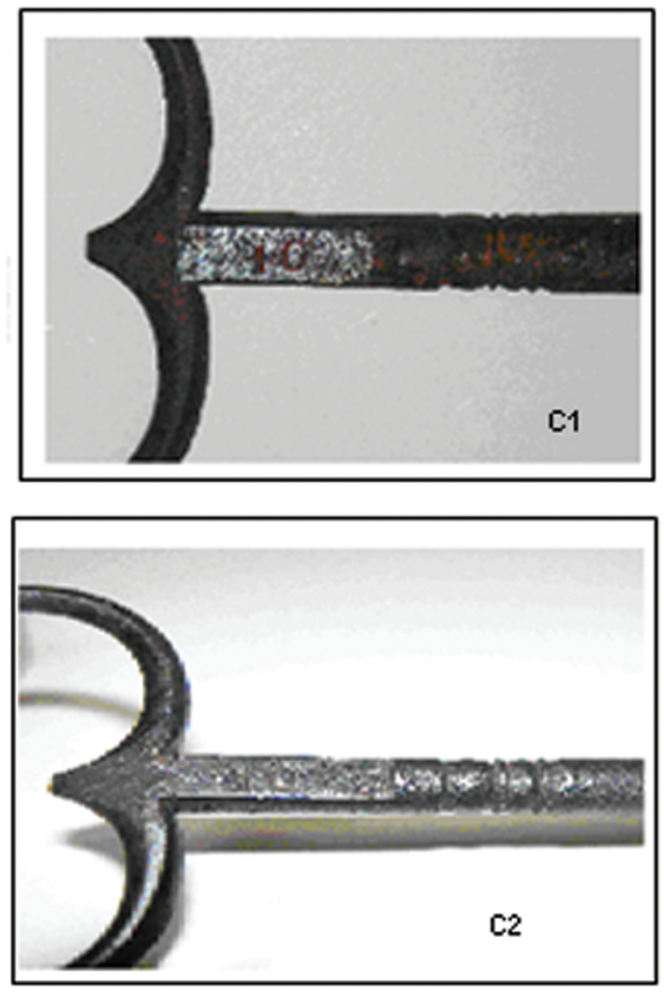

Fig. 5 a -Sample object before (C1) and after (C2) mechanical cleaning.

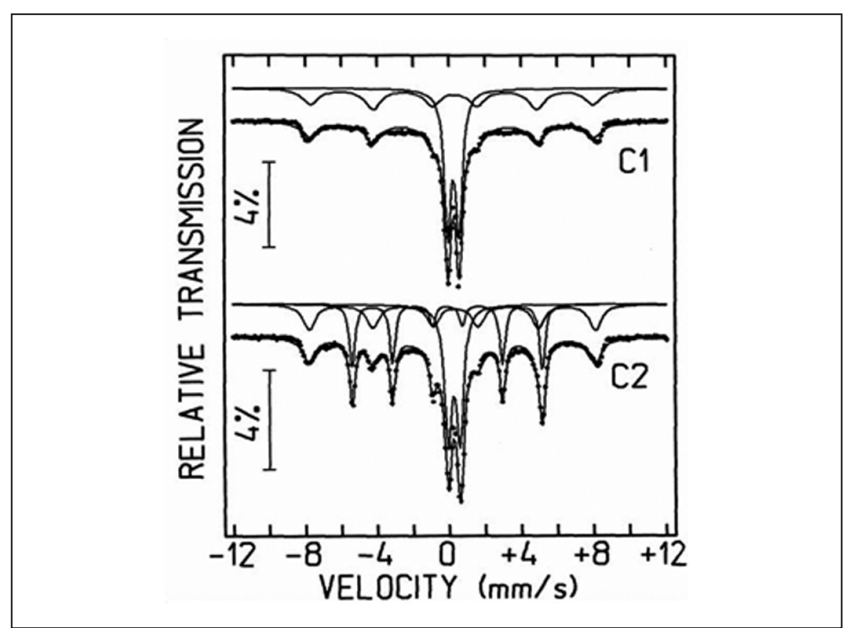

Fig. 5 b-Mössbauer analysis spectra and respective quantitative results of the compounds present on superficial corrosion (C1) and product removed (C2) by mechanical cleaning.

\subsection{Chemical cleaning}

For the chemical cleaning of corrosion, iron artefacts were immersed in aqueous solution of EDTA (Ethylene Diamine Tetra Acetic, $\mathrm{C}_{10} \mathrm{H}_{14} \mathrm{~N}_{2} \mathrm{Na}_{2} \mathrm{O}_{8} .2 \mathrm{H}_{2} \mathrm{O}$ ), in special hermetically closed containers, and heated up to $150^{\circ} \mathrm{C}$ for several hours. The dimension of the pieces that is possible to clean by this method depends on the size of the container.

Photos of the original and cleaned pieces as well as the quantitative results of Mössbauer analysis are presented on fig. 6 .

\subsection{Long pulse $\mathrm{CO}_{2}$ laser cleaning}

The iron artefacts were placed on a linear translation stage, and moved with different speeds (from 2 to $50 \mathrm{~mm} \mathrm{~s}^{-1}$ ) that combined with the pulse repetition frequency $(1 \mathrm{kHz})$ provided an overlap of irradiated spots from $90 \%$ to $99 \%$ along the spot diameter. The laser energy density incident on the metal surface was varied from 0.19 to $0.66 \mathrm{~J} \mathrm{~cm}^{-1}$.

The removal of corrosion was observed at higher fluencies, but also a darkening of the irradiated substrate, mainly at the centre of the irradiated spot (Fig. 7). The processing time was about \pm 1 min per irradiated $\mathrm{cm}^{2}$. 


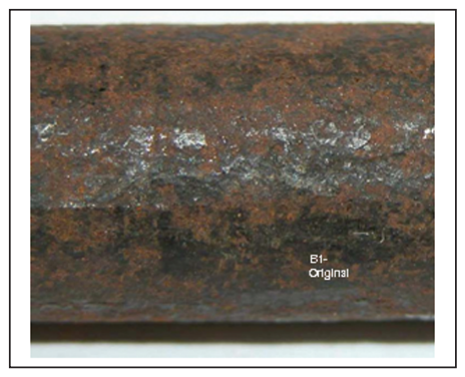

\begin{tabular}{|l|r|}
\hline $\mathrm{Fe}-\alpha$ & $11.8 \%$ \\
$\mathrm{Fe}(\mathrm{OH})_{3}$ & $60.3 \%$ \\
$\alpha-\mathrm{Fe}_{2} \mathrm{O}_{3}$ & $6.0 \%$ \\
$\mathrm{Fe}_{3} \mathrm{O}_{4}(\mathrm{~A})$ & $8.9 \%$ \\
$\mathrm{Fe}_{3} \mathrm{O}_{4}(\mathrm{~B})$ & $13.0 \%$ \\
\hline
\end{tabular}
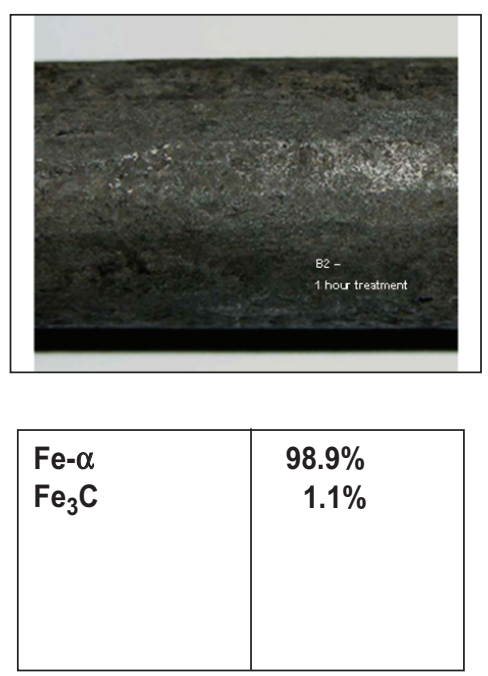

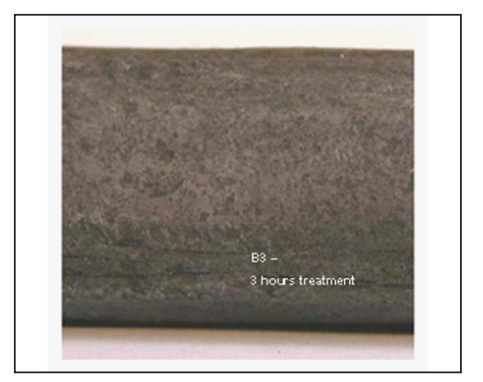

\begin{tabular}{|l|r|}
\hline $\mathrm{Fe}-\alpha$ & $96.2 \%$ \\
$\mathrm{Fe}_{3} \mathrm{C}$ & $3.8 \%$ \\
& \\
& \\
& \\
\hline
\end{tabular}

Fig. 6 - Mössbauer analysis quantitative results of samples removed from surface of original object (B1), surface of object immersed during 1 hour (B2) and surface of object immersed during 3 hours (B3).
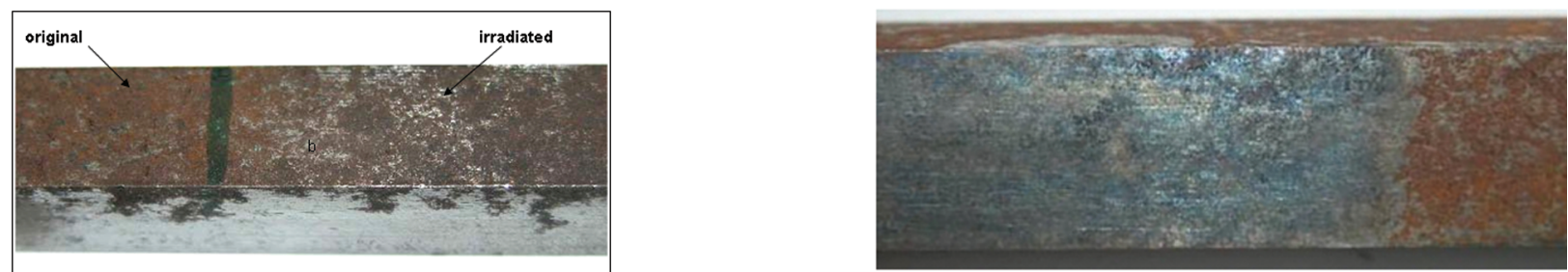

Fig. $7-\mathrm{CO}_{2}$ laser irradiated spot (left) and overexposed darkened area (right).

\subsection{Short pulse Nd:YAG laser cleaning}

The Palladio laser system is a Q-Switched Nd:YAG laser equipped with an articulated arm; the manual use of this articulated arm together with a much lower pulse repetition frequency (single pulse, 1 or $2 \mathrm{~Hz}$ ), allowed for a manual positioning of the laser beam and a controlled number of pulses where it was needed. Fixed laser energy density was used $\left(0.14 \mathrm{~J} \mathrm{~cm}^{-2}\right)$ and the number of pulses on the same area was varied.

Removal of corrosion was observed (fig. 8 ) by naked eye with a single pulse; with 10 pulses the shining grey colour of the iron substrate was clearly visible; with 120 pulses incident in the same position, a darkening of the irradiated area was observed. After irradiation it was not detected a significant temperature increase of the object.

Mössbauer spectroscopy analysis of samples removed from the surface of the objects after laser cleaning showed that complete corrosion removal, iron oxides and hydroxides, was never achieved (fig. 9) with any laser system. Although the remaining corrosion on the surface of the object cleaned with the $\mathrm{Nd}$ :YAG Laser is more abundant. This is (probably) due to an incomplete intervention.

In both laser cleaned surfaces, no other iron compounds shown up, unlike for the mechanical and chemical cleaning where cementite $\left(\mathrm{Fe}_{3} \mathrm{C}\right)$, an iron compound not found in the surface of the original corroded object. Once cementite is an compound found in the bulk of the iron objects, this fact is a demonstration of the selectivity of the laser cleaning process, removing (partially) the corrosion, but stopping at the corrosion-substrate interface, and not "attacking" the original artefact surface.

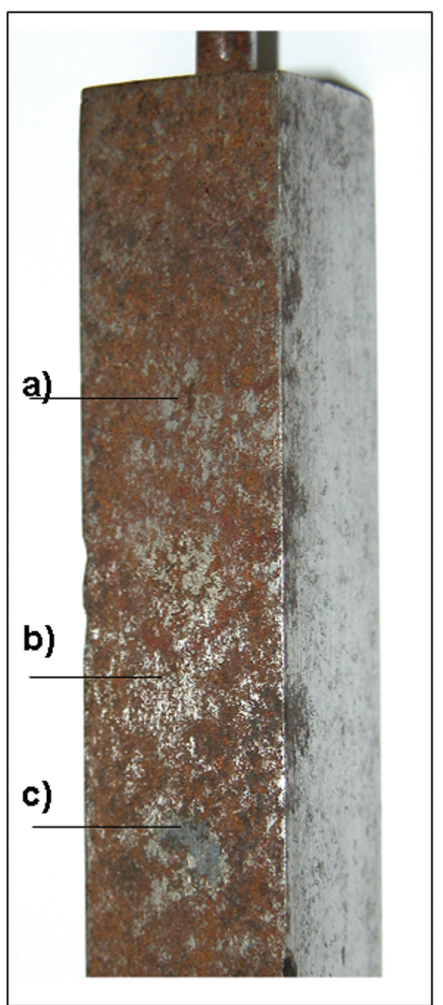

Fig. 8 - Nd:YAG Laser cleaning testes. a) slight removal of surface corrosion; b) visible removal of surface corrosion; c) Corrosion removal with surface modification. 


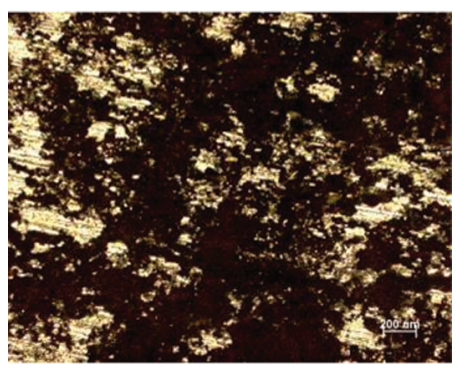

a) Single pulse

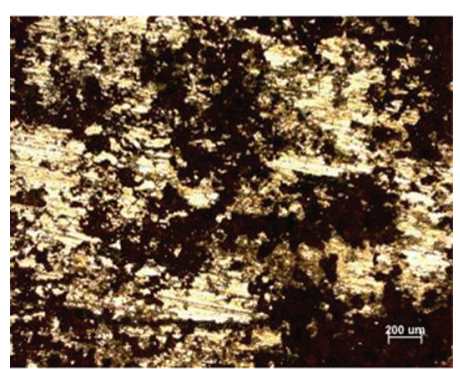

b) 10 pulses ( 5 sec.)

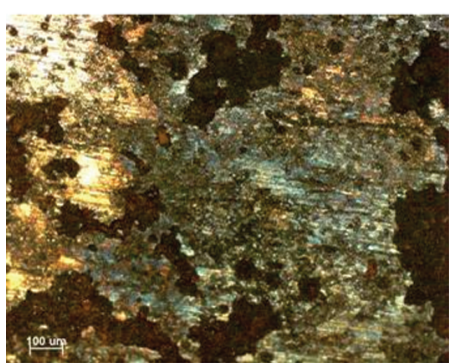

c) 120 pulses (1 minute)
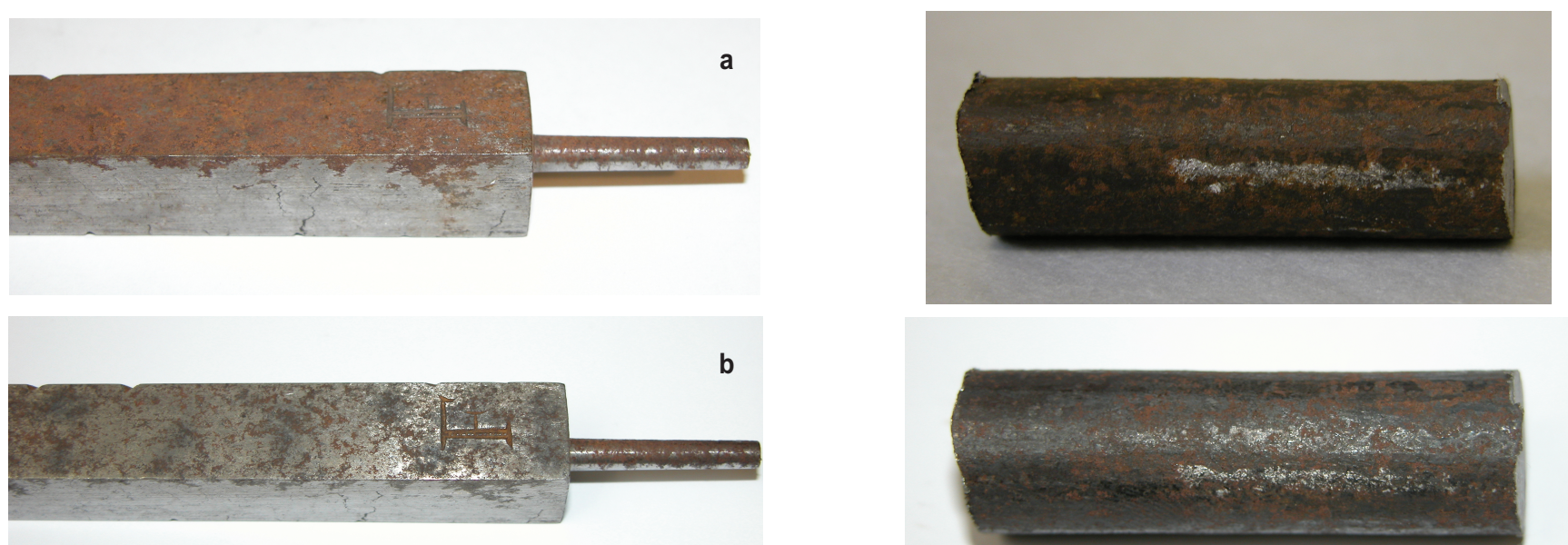

a

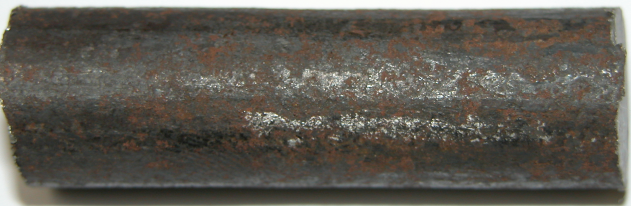

b

Fig. 9 - Corroded artefacts before (a) and after Q-Switched Nd:YAG Laser cleaning (b).

Figure 10 shows the spectra of four representative essays of the A set of samples (samples obtained in similar

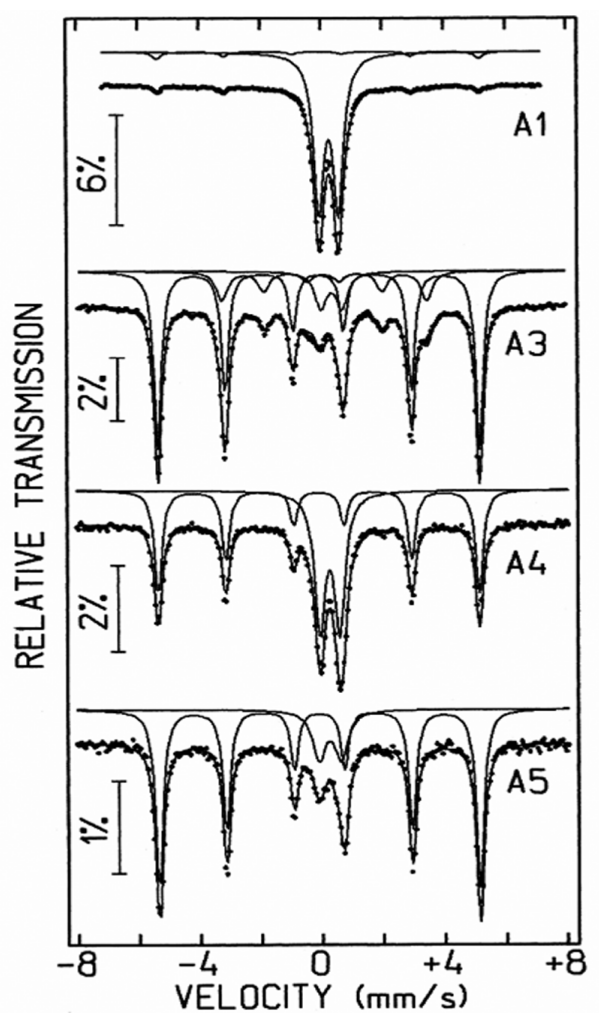

corrosion areas), before and after the application of the three different techniques of cleaning.

\begin{tabular}{|c|c|c|c|}
\hline A1 & original & $\begin{array}{l}\mathrm{Fe}-\alpha \\
\mathrm{Fe}(\mathrm{OH})_{3}\end{array}$ & $\begin{array}{l}6.7 \% \\
93.3 \%\end{array}$ \\
\hline A3 & mechanical & $\begin{array}{l}\mathrm{Fe}-\alpha \\
\mathrm{Fe}(\mathrm{OH})_{3} \\
\mathrm{Fe} 3 \mathrm{C}\end{array}$ & $\begin{array}{l}71.0 \% \\
11.0 \% \\
18.0 \%\end{array}$ \\
\hline A4 & $\begin{array}{l}\text { LASER } \\
\text { (Nd:YAG - Q-Switch) }\end{array}$ & $\begin{array}{l}\mathrm{Fe}-\alpha \\
\mathrm{Fe}(\mathrm{OH})_{3}\end{array}$ & $\begin{array}{l}52.3 \% \\
47.7 \%\end{array}$ \\
\hline A5 & $\begin{array}{l}\text { LASER } \\
\left(\mathrm{CO}_{2}\right)\end{array}$ & $\begin{array}{l}\mathrm{Fe}-\alpha \\
\mathrm{Fe}(\mathrm{OH})_{3}\end{array}$ & $\begin{array}{l}81.3 \% \\
18.7 \%\end{array}$ \\
\hline
\end{tabular}

Fig. 10 - Mössbauer spectra and quantitative results of samples removed from original corroded object (A1), mechanical cleaned surface (A3), $\mathrm{Nd}$ :YAG laser cleaned surface (A4) and $\mathrm{CO}_{2}$ laser cleaned surface (A5). 
SEM and EDX were also used for qualitative evaluation of laser cleaning of iron artefacts (fig. 11 and 12).

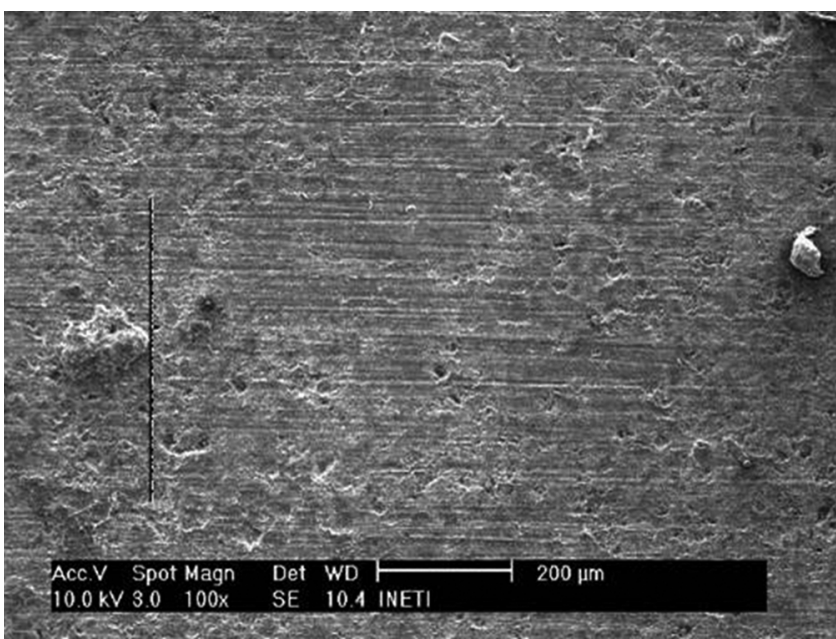

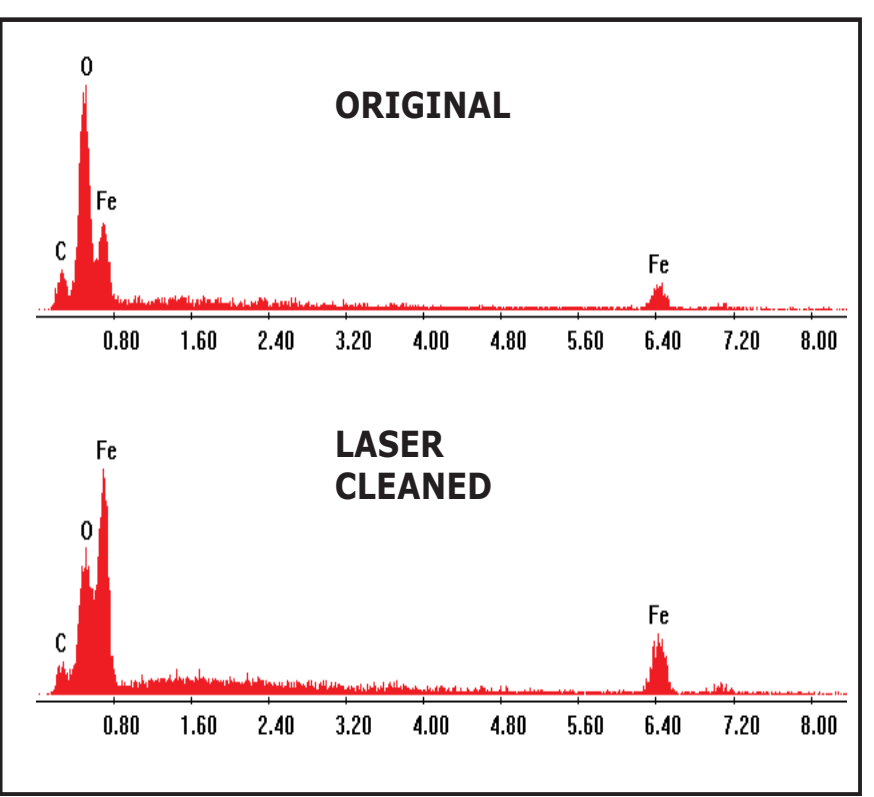

Fig. 11 - SEM micrograph and EDX spectra of cleaned area.

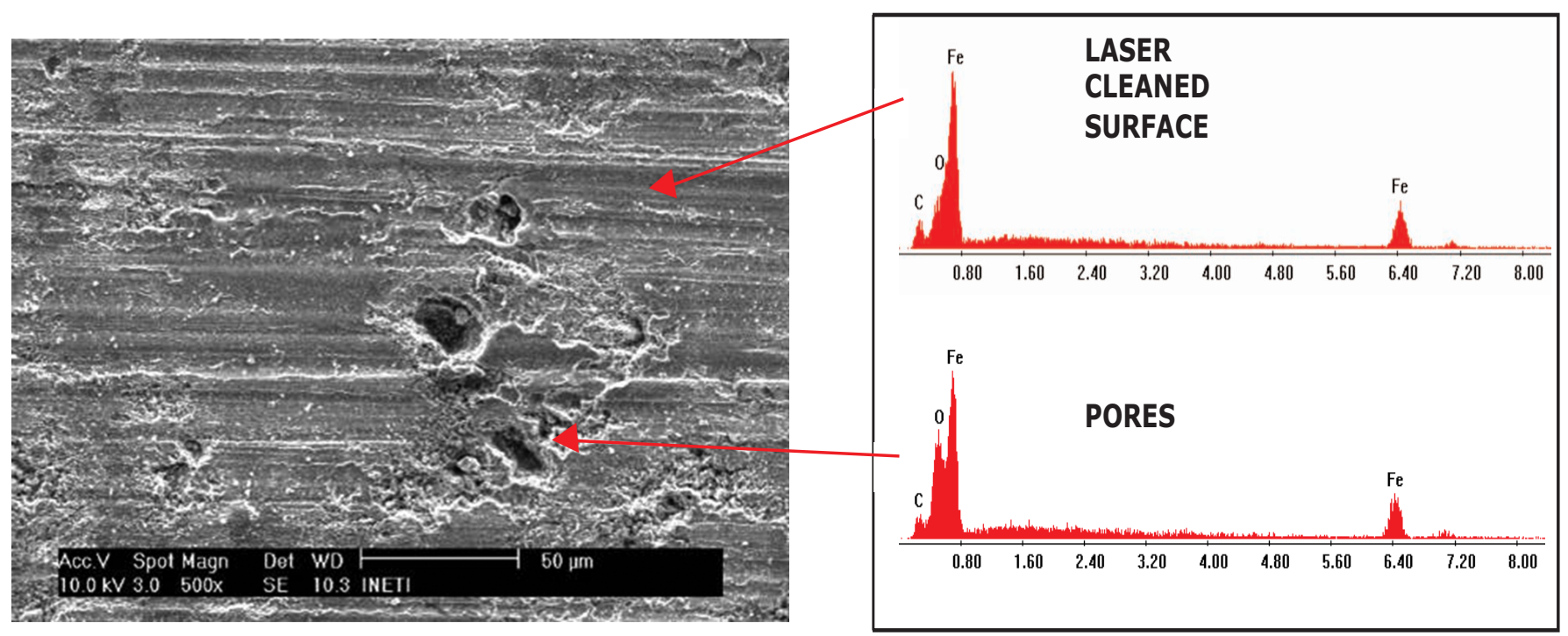

Fig. 12 - SEM micrograph and EDX spectra of pores in the cleaned area.

Fig. 11 shows a SEM micrograph of a cleaned area on the object surface, and the elemental spectra presented show the dear decrease of the Oxygen peak, relative to the iron, indicating the decreasing of corrosion products. Fig. 12, with a larger magnification, allows the conclusion that part of the unremoved corrosion is hosted in deep pores existing in the object's surface.

\section{CONCLUSIONS}

Laser cleaning has been applied to corroded iron artefacts, with two different laser sources, a long pulse $\mathrm{CO}_{2}$ Laser, and a short pulse Q-Switched Nd:YAG Laser. Moreover mechanical and chemical cleaning of the same objects took place, and the efficiency and selectivity of these different cleaning techniques was compared.

It was verified that, although not as so effective as chemical or mechanical cleaning, laser radiation removed selectively the iron corrosion products, without damaging the substrate.
When comparing pulsed $\mathrm{CO}_{2}$ and Q-switched Nd:YAG it was observed a darkening of the object surface in the area irradiated by the $\mathrm{CO}_{2}$ laser, that was associated with a heavier thermal load caused by the irradiations conditions.

Comparing the two systems of LASER cleaning in the objects of set $A$, we can conclude that pulsed $\mathrm{CO}_{2}$ Laser is more efficient than $\mathrm{Nd}: Y A G-Q-S w i t c h ~ L A S E R$ in the removal of $\mathrm{Fe}(\mathrm{OH})_{3}$.

Laser cleaning also showed to be a faster process, possible to be directed to the desired points or parts of the object, even with complex geometrical shapes, and usable indoors or outdoors.

\section{REFERENCES}

[1] J. F. ASMUS, C. G. MURPHY and W. H. MUNK (Studies on the Interaction of Laser Radiation with Art Artefacts) in Proceedings. of the Society of Photo-Optical Instrument Engin, 41, p. 19 (1973). 
[2] J. F. ASMUS, Technology \& Conservation, Fall, p. 14 (1978).

[3] J. F. ASMUS, Interdisc. Science Rev., 12, 2, 171 (1987).

[4] P. LEAVENGOOD, J. TWILLEY and J. F. ASMUS, J. Cultural Heritage, 1, S 71 (2000).

[5] J. F. ASMUS (Laser Conservation in Palaeontology) in SPIE Proc. - Laser Techniques and Systems in Art Conservation ( $R$. Salimbeni ed.), June, Munich, Germany (2001).

[6] J. F. ASMUS and M. ABRAHAM (Laser Dusting of Delicate Objects) in SPIE Proc. Optical Methods for Arts and Archaeology (R. Salimbeni, L Pezzati eds), June, Munich, Germany (2005).

[7] A. KEARNS et al., Appl. Surf. Sci., 127, 773 (1998).

[8] J. M. LEE and K. G. WATKINS, Lasers in Engineering, 8, 3, p. 229 (1999).

[9] P. PASQUET et al., Appl. Phys. A, 69, 1, S727 (1999).

[10] P. MEJA et al., Appl. Phys. A, 69, 1, S-687 (1999).

[11] J. M. LEE and K. G. WATKINS, The Industrial Laser User, 18, 29 (2000).

[12] P. PSYLLAKI and R. OLTRA, Mater. Sci. \& Eng., A, 282, 145 (2000).

[13] K. WATKINS and J. LEE, Opt. Express, 7, 2, 69 (2000).

[14] P. PASQUET et al., (Laser Cleaning of Oxidized Fe-Alloys) in Proceedings of. XIV Int. Conf. Surface Modification Technologies, September, Paris, France (2000).

[15] P. PASQUET et al., (Laser Cleaning of Oxidized Metallic Materials: Role of the Optical Properties of the Oxide Film) in SPIE Proc. of Laser Techniques and Systems in Art Conservation (R. Salimbeni ed.) June, Munich, Germany, (2001).
[16] S. SIANO and R. SALIMBENI, Stud. Conserv., 46, 269 (2001).

[17] J. HILDENHAGEN and K. DICKMANN, Journal of Cultural Heritage, 4, S-174 (2003).

[18] E. DRAKAKI et al., Appl. Phys. A, 79, 4-6, 1111 (2004).

[19] T. BURMESTER et al., (Femtosecond Laser Cleaning of Metallic Cultural Heritage and Antique Artworks) in Proc. LACONA V (K. Dickman, C. Fotakis, J. F. Asmus eds), September, Osnabrueck, Germany (2003).

[20] P. MOTTNER et al., (Laser Cleaning of Metal Surfaces Laboratory Investigations) in Proc. LACONA V (K. Dickman, C. Fotakis, J. F. Asmus eds.), September, Osnabrueck, Germany (2003).

[21] S. BATISHCHE et al., (1320 nm Range Nd:YAG Laser in Restoration of Artworks made of Bronze and Other Metals) in Proc. LACONA V (K. Dickman, C. Fotakis, J. F. Asmus eds), September, Osnabrueck, Germany (2003).

[22] Y. KOH and I. SARADY (Surface Cleaning of Iron Artefacts by Lasers) in Proc. LACONA V (K. Dickman, C. Fotakis, J. F. Asmus eds), September, Osnabrueck, Germany (2003).

[23] K. DICKMANN et al., (Archaeological Ironwork: Removal of Corrosion Layers by Nd:YAG Lasers) in Proc. LACONA V (K. Dickman, C. Fotakis, J. F. Asmus eds), September, Osnabrueck, Germany (2003).

[24] M. AUTRIC and R. OLTRA (Basic Processes of Pulsed Laser Materials Interaction. Applications to Laser Cleaning of Oxidized Surfaces) in SPIE Proc. XV Int. Symp. on Gas Flow, Chemical Lasers and High Power Lasers (J. Kodimova ed.), March, Prague, Czech Rep. (2005). 